\title{
Determinants of Portfolio Turnover for Equity Mutual Funds
}

\author{
Pedro Luiz Albertin Bono Milan ${ }^{\dagger}$ \\ Getulio Vargas Foundation \\ William Eid Junior ${ }^{\Omega}$ \\ Getulio Vargas Foundation
}

\begin{abstract}
Active management of a mutual fund aims to obtain a better return than a representative market portfolio, by means of regularly adjusting the composition of the fund's portfolio of securities. This study investigates the determinants of the portfolio turnover indexes of actively managed stock investment funds in the Brazilian market. By applying the method developed by Gaspar, Massa and Matos (2005), we show how the characteristics of funds and their managers affect their level of portfolio turnover. Large funds and those that require high initial deposits tend to present higher turnover, as is the case of funds having longer manager tenure. In contrast, the longer the manager's experience is, the lower the turnover tends to be. Finally, managers with business administration degrees tend to be more active traders than those trained in economics or engineering.
\end{abstract}

Keywords: Determinants. Mutual funds. Stock funds. Turnover.

*Author for correspondence:

${ }^{\dagger}$. Master's Degree from the São Paulo School of Business Administration of Getulio Vargas Foundation.

Institution: Researcher at the São Paulo School of Business Administration of Getulio Vargas Foundation.

Address: Av. Nove de Julho, 2029, São Paulo $\mathrm{SP}$ - Brazil

E-mail: pedro.albertin@gvmail.br

Telephone: (11) 3799-7994

\footnotetext{
${ }^{\Omega}$ Postdoctorate from the School of Economics, Administration and Accounting of the University of São Paulo Institution: Tenured Professor at the São Paulo School of Business Administration of Getulio Vargas Foundation.

Address: Av. Nove de Julho, 2029, São Paulo

- SP - Brazil

E-mail: william.eid@fgv.br

Telephone: (11) 37997994
}

Note from the Editor: The article was accepted by Emerson Mainardes. 


\section{INTRODUCTION}

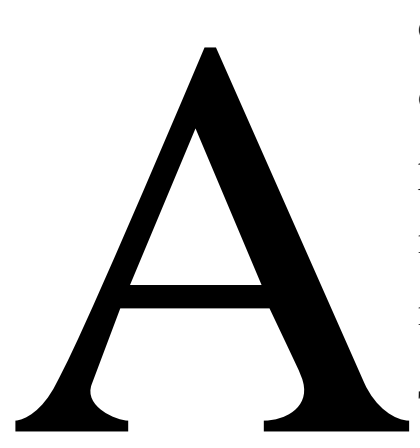

ctively managed stock investment funds constantly change the composition of their portfolios seeking to obtain better returns than a market-tracking portfolio. According to the BM\&FBovespa, the objective of active management is to generate a better return than a market portfolio, measured by a reference or benchmark of the fund.

To beat the general market or benchmark return, the managers of actively traded funds regularly change the portfolio composition by buying and selling stocks and other securities, according to a defined strategy. This management strategy directly affects the portfolio composition and level of turnover.

According to Instruction 409, issued on August 18, 2004 by the Brazilian Securities Commission (CVM), 67\% of the net assets of stock investment funds must be invested in shares traded on exchanges or organized over-the-counter markets, stock subscription rights, stock certificates of deposit, shares of exchange-traded stock funds and Brazilian Depositary Receipts classified at Level II or III.

Actively managed funds are the main vehicles used by retail investors to participate in the equity market. According to Golec (1996), the management strategy and characteristics of the fund and its manager are influenced by various factors, affecting the fund's performance and the level of portfolio turnover, by leading the fund to be more or less active in changing the composition of its portfolio. The fund's characteristics, and consequently the investment policy and ability to attract investors, depend on the benchmark, time of existence and net asset value, among other factors. The characteristics of the managers, such as experience, professional training and time managing the fund, among others, also can influence the performance and level of turnover. In this respect for example, Chevalier and Ellison (1999b) found that managers with degrees from more prestigious universities and younger managers tended to outperform other managers in terms of risk-adjusted returns.

Considering the high volume of resources invested in actively managed stock funds in Brazil and the impact of these funds' strategy on their performance, here we investigate the determinants of the portfolio turnover index of stock funds, to improve understanding of the factors that differentiate funds and the reasons that lead funds to have different portfolio turnover indexes. We rely on the method described by Gaspar, Massa and Matos (2005) to measure turnover, employing data on the composition of portfolios and the characteristics of 
the funds and their managers.

The results indicate that the characteristics of the funds and managers affect the portfolio turnover. Larger funds (in terms of net asset value) and funds that require higher initial investments tend to present higher portfolio turnover levels. Managers with more time dedicated to the same fund also tend to produce higher turnover. However, the longer the experience of managers, measured by years engaged in the activity, the lower the portfolio turnover tends to be. Finally, managers with degrees in business administration tend to produce greater turnover indexes than those with degrees in economics or engineering.

This study is structured in five sections including this introduction. The second section reviews the literature on the theme, summarizing the main studies; the third section presents the data and method adopted to analyze them; the fourth section presents and discusses the results obtained from the model; and the fifth section contains our final remarks.

\section{LITERATURE REVIEW}

Markowitz (1952) was a pioneer in presenting the concepts of diversification and application of mathematical models to measure the risk of keeping resources invested in a single asset. By diversification, an investor can diminish the risk without losing financial returns. The ensuing theoretical discussion about the construction and diversification of portfolios prompted the development of active portfolio management activity, for diversification both to reduce risks and to achieve financial gains by taking advantage of market opportunities.

The turnover levels of funds are influenced by various factors and the returns can vary accordingly. The factors can be, among others, the background of portfolio manager and the investment policy of the fund on one side, and the corporate strategy, profit history, structure and perceived skills of the executives of the companies issuing stocks on the other side, besides external factors. The selection of a fund manager, for example, depends on diverse criteria, among them academic training, history of returns of other funds managed previously or concurrently, length of experience in the market and ability to form and manage teams. Although an extensive literature exists dedicated to measuring the performance of mutual funds, the investigation of internal and external factors that distinguish funds and their returns is still an emerging field for research.

Golec (1996) evaluated the interplay of the characteristics of managers, characteristics of funds, management strategy and performance of mutual funds, finding that managers 
holding MBAs deliver worse results than those without master's degrees, besides the absence of a significant relation between the ability to generate excess returns and the level of portfolio turnover, fund's beta, size of the management team, age of the manager, fund's net asset value and manager's education. Chevalier and Ellison (1997, 1999a, 1999b) studied the relation between incentives to managers and the returns generated, the ability to evaluate portfolio risk by market experience of the manager and the relation between performance on the one hand and education and personal experience of the investor on the other. Among the findings were that fund managers who attended more selective universities produce higher risk-adjusted excess returns, as do younger managers in relation to older ones.

Many studies have tried to disaggregate the performance in function of investing style (or investment objective) of mutual fund managers. These investigations are motivated by an attempt to identify whether managers with different investment approaches provide better returns to clients (Grinblatt and Titman, 1989, 1993; Elton et al., 1993; Gruber, 1996); Becker et al., 1999). Daniel et al. (1997) also analyzed the performance with references that represent differences in the characteristics of mutual fund managers.

Sanvicente (2002) examined the obtainment of resources by investment funds according to the benchmark chosen, and tried to show the determinants for obtaining resources. The results revealed an increase in resources under management by funds referenced to the main Brazilian market-tracking index, the Ibovespa, three days after good news about that index.

Gallagher (2003) analyzed the role of human capital on the performance of funds, measured in years of study by managers. The results demonstrated that years of study do not explain excess risk-adjusted return. The systemic risk is positively related to the age of a fund administration institution and negatively related to the tenure of the senior portfolio manager and portfolio management strategies. The performance fees are positively related with the benchmarks of stock investment funds, years of education of the manager, tenure managing the same fund and years of experience of managers. Besides these findings, the study identifies a large proportion of stock fund managers that generated high risk-adjusted returns in the period studied. These results are consistent with those obtained by Daniel et al. (1997), Wermers (2000) and Cesari and Panetta (2002).

Leusin and Brito (2008) evaluated the performance of stock investment funds in the Brazilian market between 1998 and 2003 to better understand the role of managers, finding evidence that the minority of the funds studied had managers with good market timing ability. 
More recently, Afza and Rauf (2009) investigated the impact of various factors on the performance of Pakistani mutual funds. The factors were: lagged returns, fund age, loading, liquidity, turnover and expenses, among others. The results indicated that the risk-adjusted returns are positively correlated with turnover, age and expenses, although with low statistical significance.

Considering that most stock investment funds have a dynamic portfolio and are affected by many factors, Matos and Rocha (2009) investigated factors that differentiated funds and their returns by applying pricing and forecasting models. They found that the size factor, measured by net asset value, is a relevant factor to measure returns. Funds with high net asset values are harder to analyze by the Capital Asset Pricing Model (CAPM), in comparison with the three-factor model of Fama and French (1993) and the four-factor model of Carhart (1997).

Eid and Rochman (2009) analyzed whether active management adds or destroys value of Brazilian investment funds, investigating four types of funds: stock, fixed-income, hedge and exchange rate. The authors found evidence that active management adds value to investors in stock and hedge funds, and for these two fund types, older, larger and actively managed funds generate higher alphas. Overall, the results shed light on the factors responsible for performance and the actions of managers.

Matos and Castro (2012) examined stock investment funds in Brazil and presented a dynamic ranking of funds by applying different performance metrics. They found evidence of different return persistence levels among better-performing funds, due to the ability of managers. The study indicates the importance of managers' ability and serves as a basis for the present study in the comprehensive analysis of the effect of managers' characteristics on the portfolio turnover of funds, which is a tool used by managers seeking to achieve better returns by taking advantage of market opportunities.

\section{DATA AND METHODOLOGY}

This study covers the period from January 2007 to December 2011, with a sample composed of 47 stock investment funds, according to the definition of the Brazilian Association of Financial and Capital Market Entities (ANBIMA), responsible for selfregulation and representation of all agents active in the Brazilian capital market.

We only study actively managed, non-exclusive and open-ended funds, composed variously of retail, selective retail, private, institutional and/or corporate investors. The funds 
chosen had net asset value of at least $\mathrm{R} \$ 5$ million, 50 or more investors and activity of five years or more, in line with the study period. The restrictions are arbitrary, aiming to avoid distortions in the analysis due to small funds according to value or number of investors.

There were 75 funds that ceased to exist during the five-year study period, which we excluded from the tests and analyses despite the risk of survival bias, because of the absence of complete or reliable data on the manager/fund characteristics and turnover. Besides these problems, many of the funds that ceased to exist during the study period did not have the characteristics necessary to compose the sample because of our arbitrary restrictions.

To find the determinants of the portfolio turnover indexes, we measured the turnover index of each fund and checked whether the characteristics of the funds and their managers could explain the turnover.

The time-series data on the composition of the funds' portfolios was obtained from Quantum, a financial technology firm specialized in providing solutions to access, analyze and compare financial information, by means of its Quantum-Axis® platform. The data on the characteristics of the funds and managers were obtained from the Anuário da Indústria de Fundos de Investimento (GVCef/ANBIMA).

Table 1 summarizes the descriptive statistics on the funds in the sample. The average number of investors is 30 thousand, meaning they can be classified on average as being large funds in terms of number of clients. Twenty-five charge a monthly performance fee, with an average rate of $2.57 \%$. The average minimum initial investment is $\mathrm{R} \$ 23$ thousand, the mean net asset value is $\mathrm{R} \$ 191$ million and the average age is 11 years.

With respect to the managers, the average tenure managing the same fund is 10 years and the average experience in the fund market in general is 19 years (with a 7-year standard deviation). Their average age is 43 years, and $53.19 \%$ have degrees in business administration, followed by $25.53 \%$ in economics and $21.27 \%$ in engineering. 
Table 1 - Descriptive Statistics of the Characteristics of the Funds and Managers

\begin{tabular}{|c|c|c|c|c|c|}
\hline Variable & Mean & Median & $\begin{array}{c}\text { Standard } \\
\text { Deviation }\end{array}$ & Minimum & Maximum \\
\hline & & $124,412,088$ & & $14,602,203$. & $729,571,568$. \\
\hline Net Assets (NA) & $191,450,541.60$ & 51 & $170,974,149.59$ & 46 & 58 \\
\hline Fund Age (years) & 11 & 10 & 6 & 5 & 32 \\
\hline Management Fee (\%) & 2.58 & 2.50 & 1.03 & 0.60 & 5.00 \\
\hline Performance Fee $(\%)$ & 8.72 & 0.00 & 9.86 & 0.00 & 20.00 \\
\hline Initial Deposit (R\$) & $23,142.55$ & $10,000.00$ & $28,349.90$ & 100.00 & $100,000.00$ \\
\hline Number of Investors & 30,608 & 422 & 136,746 & 50 & 709,944 \\
\hline Manager's Age (years) & 43 & 45 & 8 & 31 & 59 \\
\hline $\begin{array}{l}\text { Tenure Managing the Fund } \\
\text { (years) }\end{array}$ & 10 & 11 & 4 & 1 & 15 \\
\hline $\begin{array}{l}\text { Manager's Market Experience } \\
\text { (years) }\end{array}$ & 19 & 20 & 7 & 7 & 37 \\
\hline $\begin{array}{l}\text { Manager's Academic Training } \\
\text { (years) }\end{array}$ & $\begin{array}{r}\text { Bus. } \\
\text { Administration }\end{array}$ & Economics & Engineering & & \\
\hline & 25 & 12 & 10 & & \\
\hline
\end{tabular}

Note. Source: Prepared by the authors. The table summarizes the statistics on the characteristics of the funds and managers, which are the explanatory variables in the regression model.

To estimate the portfolio turnover indexes (1), we relied on the integrated model of asset buying and selling to compose an investment portfolio formulated by Gaspar, Massa and Matos (2005), who in turn followed the theory developed by Carhart (1997), Barber and Odean (2000) and CRSP (2003).

$$
\mathrm{CR}_{i, t}=\frac{\sum_{j}\left|N_{j, i, t} P_{j, t}-N_{j, i, t-1} P_{j, t-1}-N_{j, i, t-1} \Delta P_{j, t}\right|}{\Sigma_{j} \frac{N_{j, i, t} P_{j, t}+N_{j, i, t-1} P_{j, t-1}}{2}}
$$

Where CRi,t denotes the portfolio turnover (churn rate) of investment fund $i$ for month $t, j$ is the firm that issued the stock, $i$ is the investment fund, $t$ is the month of publication of the portfolio's composition, $P j, t$ corresponds to the price per share of firm $j$ for month $t, P j, t-1$ is the price per share of firm $j$ for the month before $t, N j, i, t$ is the number of shares of firm $j$ composing the portfolio of fund $i$ in month $t, N j, i, t-1$ is the number of shares of company $j$ composing the portfolio of fund $i$ in the month before $t$ and $\Delta P j, t$ is the variation in the stock price of firm $j$ in month $t$ in relation to the previous month.

Gaspar, Massa and Matos (2005) investigated, in the American market, the impact on corporate governance of firms given the investment horizon of institutional investors, in light of the stock portfolio turnover index, called the churn rate (CR). This metric was constructed to analyze and measure the stock buying and selling of institutional investors over their investment horizons, thus allowing estimating the influence of this buying and selling activity on corporate control and governance. The model estimates the relation between the number of 
shares purchased and sold and the stock price, excluding the price variation between the month analyzed and the preceding month. By adding the relação de compras e vendas por empresa emitente da ação [=ratio of the shares of each firm bought and sold? number of shares of each firm bought and sold?], the index is positive and represents the total movement in the portfolio in each period analyzed.

The portfolio turnover indexes, estimated by Equation (1) and presented in Table 2, have average of $19.90 \%$ and standard deviation of $7.53 \%$. This means that the studied funds altered an average of $19.90 \%$ of the securities held each month during the study period by buying and selling, showing that these funds are actively managed to try to take advantage of market opportunities.

Table 2 - Descriptive Statistics of the Portfolio Turnover Indexes

\begin{tabular}{lrrcrr}
\hline Variable & Mean & Median & Standard Deviation & Minimum & Maximum \\
\hline Turnover (\%) & 19.9029 & 19.6305 & 7.5334 & 1.8390 & 35.8301
\end{tabular}

Note: Source: Prepared by the authors. The table summarizes the statistics of the portfolio turnover indexes, calculated from Equation 1.

To evidence the determinants of the funds' turnover indexes, we followed the methodology employed by Golec (1996) to test the impact of the characteristics of funds and their managers on the performance of American mutual funds, by applying a regression model.

Likewise, we applied the regression model specified by (2) to identify the factors that influence the portfolio turnover, with the following variables:

Response variables: Portfolio turnover indexes.

Predictor variables: Net Assets, Benchmark, Client Type, Fund Age, Management Fee, Performance Fee, Initial Deposit, Number of Investors, Manager's Academic Training, Manager's Market Experience and Manager's Tenure with the Fund.

The regression model to identify the determinants of the turnover index is defined by the following equation:

$$
\begin{gathered}
\text { Turnover }_{i}=\beta_{0}+\beta_{1} \text { Ln }_{\left(P L_{i}\right)}+\beta_{2} \text { Benchmark }_{i}+\beta_{3} \text { ClientTypeDummy }_{i}+\beta_{4} \text { FundAge }_{i} \\
\beta_{5} \text { ManagementFee }_{i}+\beta_{6} \text { PerformanceFeeDummy }_{i}+\beta_{7} \text { InitialDeposit }_{i} \\
\beta_{8} \text { NumberInvestor }_{i}+\beta_{9} \text { MManagementDummy }_{i}+\beta_{10} \text { EconomyDummy }_{i} \\
\beta_{11} \text { ManagerExperience }_{i}+\beta_{12} \text { ManagerTenure }+\varepsilon_{i}
\end{gathered}
$$




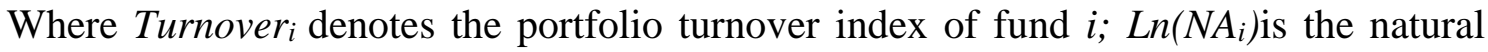
logarithm of the net asset value of fund $i$; Benchmark $i$ is the market reference index used by fund $i$; ClientTypeDummy $y_{i}$ is an indicator variable for the type of client served by fund $i$; $F_{\text {undaAge }}$ corresponds to the age in years of fund $i$; ManagementFee $e_{i}$ is the management fee charged by fund $i$; PerofrmanceFeeDummy $y_{i}$ is an indicator variable of whether or not fund $i$ charges a performance fee; InitialDeposit ${ }_{i}$ denotes the initial deposit required to invest in fund $i$; NumberInvestors $s_{i}$ is the number of investors of fund $i$; AdministrationDummy $y_{i}$ is an indicator variable for managers with degrees in business administration of fund $i$; EconomicsDummy $_{i}$ is a similar indicator variable for managers of fund $i$ with degrees in economics, ManagerExperience $e_{i}$ denotes the number of years of previous experience of the manager of fund $i$ and ManagerTenure $e_{i}$ corresponds to the time managing the same fund by the current manager of fund $i$.

The variable ClientTypeDummy indicates two types of clients predominantly served by the fund: one group made up of retail investors and the other composed of selective retail, private and corporate clients. The variable PeformanceFeeDummy $y_{i}$ divides the sample into funds that charge and do not charge a performance fee (due to the similarity of the percentages applied by funds that do charge such fees). Finally, the AdministrationDummy and EconomicsDummy variables aim to find differences due to the academic training of the managers, which can be business administration, economics or engineering.

Our choice of variables follows the definition of Golec (1996). The fund's age represents the survival ability, prestige and loyalty of investors. The net asset value and number of investors represent the market's acceptance, past returns and scale economies of the fund. The existence of a performance fee indicates the confidence of the manager in the ability to obtain better returns than a market portfolio. The management fee represents the remuneration for the effort of the management team in conducting operational processes. The initial deposit, type of client and benchmark complete the list of fund characteristics included in the model.

Golec (1996) assessed the characteristics of managers and the performance of mutual funds and found that managers holding MBAs delivered worse results than those not holding such degrees. He also found the absence of a significant relation between the ability to generate excess return and the turnover level, beta, management team size, manager's age, fund's net asset value and manager's years of education. 
The manager's age or years in the market can be considered a proxy for experience. Inclusion of the field of the manager's academic training in the model aims to measure whether different backgrounds affect the level of trading activity. Our sample only contained managers with degrees in business administration, economics and engineering. The tenure in managing the fund, according to Golec (1996), can reveal whether the manager has the ability to consistently generate better returns than the benchmark, or that the fund is unable to find a replacement with perspectives of obtaining better returns.

To assure the robustness of the results, before applying the model, we carried out tests to check for the existence of multicollinearity and heteroscedasticity between the explanatory variables, i.e., to verify whether or not the explanatory variables included in the model have interdependence or different variances.

According to Kutner et al. (2004) and Tamhane and Dunlop (2000), the variance inflation factor (VIF) can be used to measure multicollinearity. The White test (1980) checks the adequacy with respect to three prerequisites of linear regression models: homoscedasticity of the error terms, constant variance and independence of the error terms in relation to the regressors.

The average variance inflation factor (VIF) of the regression model developed in this study was 1.89, with maximum individual VIF of 2.68 , confirming the absence of multicollinearity. The White test's p-value was greater than 0.4313 , not allowing rejection of the null hypothesis of homoscedasticity of the error terms. The absence of multicollinearity and heteroscedasticity between the variables demonstrates the validity of applying our proposed regression model.

\section{RESULTS}

The result of applying the regression model (2), presented in Table 3, demonstrate the determinants of the portfolio turnover of actively managed stock investment funds in Brazil. 
Table 3 - Details of the Regression for Portfolio Turnover Indexes of Stock Investment Funds

\begin{tabular}{|c|c|c|c|}
\hline \multirow[t]{2}{*}{ Variables } & & \multicolumn{2}{|c|}{ Turnover Index } \\
\hline & & Coef & Sig. \\
\hline Constant & & -57.3334 & \\
\hline \multicolumn{4}{|l|}{ Fund's Characteristics } \\
\hline $\operatorname{Ln}(\mathrm{NA})$ & & 3.6472 & $* * *$ \\
\hline Benchmark & & 2.0484 & \\
\hline Client Type Dummy & & 0.2427 & \\
\hline Fund Age (years) & & 0.2989 & \\
\hline Management Fee & & -0.1752 & \\
\hline Performance Fee Dummy & & -0.5776 & \\
\hline Initial Deposit & & 0.0001 & $* *$ \\
\hline Number of Investors & & 0.0000 & \\
\hline \multicolumn{4}{|l|}{ Manager's Characteristics } \\
\hline Business Administration Dummy & & 4.7113 & $*$ \\
\hline Economics Dummy & & 1.6641 & \\
\hline Tenure Managing Fund (years) & & 0.5924 & $* *$ \\
\hline Market Experience (years) & & -0.3296 & $* *$ \\
\hline Equation & $* * *$ Sig at $1 \%$ & $* *$ Sig at $5 \%$ & $*$ Sig at $10 \%$ \\
\hline Turnover & 0.5925 & & \\
\hline
\end{tabular}

Note: Source: Prepared by the authors. The table presents the results of applying the regression model defied by Equation (2) for the portfolio turnover index. The response variable is the turnover index and the explanatory variables referring to the fund characteristics are: Ln(NA), benchmark, prevalent client type, fund age in years, management fee, performance fee, initial deposit and number of investors. The explanatory variables related to the manager characteristics are: a dummy for those holding degrees in business administration, a dummy for those holding degrees in economics, years of experience as fund managers and tenure with the same fund.

The results indicate that the funds' characteristics influence the portfolio turnover. Both the fund size (measured by net asset value) and the initial investment required have a positive effect on turnover. In other words, the higher the net asset value or the larger the up-front deposit required, the greater the turnover tends to be. This evidence suggests that funds with greater resources are more aggressive in exploiting market opportunities, altering the composition of the portfolio. Ciccotello and Grant (1996) suggested that funds with large net asset values achieve economies of scale, by diluting operational costs, and also have better bargaining power. Chen et al. (2004) also argued that funds with high asset values have advantages of scale gains, which along with bargaining power can directly affect the turnover levels of their portfolios. 
The results also demonstrate that the traits of managers also influence the turnover rate. The longer the manager's tenure, the greater the turnover tends to be. This result can indicate that managers try to justify their continuance and activity with processes of selecting stocks for purchase and sale. According to Golec (1996), turnover is a sign of the manager's effort to obtain better performance.

However, the longer the manager's experience in the market in general, the lower the movement of assets in the portfolio tended to be, indicating that more experienced managers tend to have a more passive management strategy. A similar result was found by Golec (1996) in the American market, where older managers presented lower churn rates.

The undergraduate degree held by managers also is an important factor to explain the turnover rates. Those holding business administration degrees tend to have greater turnover indexes than those holding degrees in economics or engineering. This suggests that the academic background of portfolio managers can affect their trading aggressiveness in trying to obtain better returns.

\section{FINAL CONSIDERATIONS}

This article analyzes the determinants of the portfolio turnover indexes of stock investment funds in the Brazilian market, based on data from 2007 to 2011 on the portfolio compositions and characteristics of the funds and their managers. The sample was composed of 47 stock funds according to the classification of the Brazilian Association of Financial and Capital Market Entities (ANBIMA), responsible for self-regulation and representation of those entities.

The results contribute to the literature by demonstrating the determinants of the portfolio turnover rates and the factors that distinguish investment funds. The tests applied show the impacts of the characteristics of the funds and managers on the turnover rate. In our sample, funds with higher net asset value and higher initial investment requirements presented higher turnover rates. This evidence suggests that funds with greater resources exploit market opportunities more often, altering the composition of their portfolios.

The traits of managers also affect the turnover rates. The longer the manager's tenure with the fund, the greater the turnover tends to be. This result can indicate that managers seek to justify their continuance and activity in selecting stocks for purchase and sale. On the other hand, the longer the manager's experience in the market, the lower the movement of stocks 
tends to be, indicating that more experienced managers tend to have more passive management strategy.

The undergraduate training of the managers also was an important factor to explain the funds' turnover rates. Mangers with business administration degrees tend to present higher turnover rates than those holding degrees in economics or engineering, suggesting that academic background can affect the trading strategy of managers.

Some reservations should be mentioned, such as the low number of funds in the sample and small range of academic backgrounds of the managers. The database only indicated the undergraduate qualification of the managers, with no mention of graduate studies, specialization courses or certificates in portfolio management. These matters do not invalidate the evidence obtained, but they indicate that new evidence can be found from analyzing data from larger samples or more thorough databases.

Therefore, new studies relying on more detailed databases and/or larger samples can corroborate the evidence found here, improving the explanatory power of the model, the efficiency of the estimators and the individual significance of the explanatory variables.

\section{REFERENCES}

AFAZA, T.; RAUF, A. Performance evaluation of Pakistani mutual funds. Pakistan Economic and Social Review, v. 47, p. 199-214, 2009.

ANBIMA. Classificação de fundos de investimento. Disponível em: $<$ http://portal.anbima.com.br/fundos-de-investimento/classificacao-de-fundos/classificacaoanbima-de-fundos/Pages/classificacao.aspx>. Acesso em: 13 jun. 2012.

Anuário da indústria de fundos 2012. 2012. Disponível em:

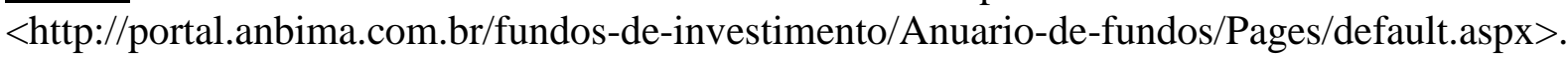
Acesso em: 10 maio 2012.

BARBER, B. M.; ODEAN, T. Trading is hazardous to your wealth the common stock investment performance of individual investors. Journal of Finance, v. 55, n. 2, p. 773-806, abr. 2000 .

BECKER, C. et al. Conditional market timing with benchmark investors. Journal of Financial Economics, v. 52, p. 119-148, 1999.

BM\&FBOVESPA. Apostila de fundos de investimento. Instituto Educacional BM\&FBOVESPA. Disponível em: <http://ebookbrowse.com/apostila-pqo-completa-pdfd132571504>. Acesso em: 12 out. 2012.

CARHART, M. On persistence in mutual fund performance. Journal of Finance, v. 52, p. 57-82, 1997. 
MATOS, P.R.F.; CASTRO, A.E.N. Fundos de investimento em ações no Brasil: performance e expertise de gestão. BBR - Brazilian Business Review, v. 10, n. 3, p. 1-38, 2013.

CESARI, R.; PANETTA, F. The performance of Italian equity funds. Journal of Banking and Finance, v. 26, p. 99-126, 2002.

CHEN, J. et al. Does fund size erode mutual fund performance? The role of liquidity and organization. The American Economic Review, v. 94, n. 5, p. 1276-1302, 2004.

CHEVALIER, J.; ELLISON, G. Risk taking by mutual funds as a response to incentives. Journal of Political Economy, v. 105, p. 1167-1200, 1997.

.;. Career concerns of mutual fund managers. Quarterly Journal of

Economics, v. 114, p. 389-432, 1999a.

.;. Are some mutual fund managers better than others? Cross-sectional

patterns in behavior and performance. Journal of Finance, v. 54, p. 875-899, 1999 b.

CICCOTELLO, C. S.; GRANT, C. T. Equity fund Size and growth: implications for performance and selection. Financial Services Review, v. 5, n. 1, p. 1-12, 1996.

CRSP. Survivor-Bias free U.S. mutual fund database guide. University of Chicago, Chicago, IL, 2003.

CVM. Comissão de Valores Mobiliários. Instrução CVM n.332, de 04 de abril de 2000. Disponível em:

<http://www.cvm.gov.br/asp/cvmwww/atos/exiato.asp?Tipo=I\&File=/inst/inst332.htm>. Acesso em: 25 out. 2012.

DANIEL, K. et al. Measuring mutual fund performance with characteristic-based benchmarks. Journal of Finance, v. 52, p. 1035-1058, 1997.

EID JUNIOR, W.; ROCHMAN, R.R. Does active management add value? The brazilian mutual fund market (July 17). Working Paper, EAESP-FGV, 2009. Disponível em: $<$ http://papers.ssrn.com/sol3/papers.cfm?abstract_id=1435323>.

ELTON, E. et al. Efficiency with costly information: a reinterpretation of evidence from managed portfolios. Review of Financial Studies, v. 6, p. 1-22, 1993.

FAMA, E.; FRENCH, K. Common risk factors in the returns on stocks and bonds. Journal of Financial Economics, New York, v. 33, p. 3-56, 1993.

GALLAGHER, D.R. Investment manager characteristics, strategy, top management changes and fund performance. Accounting \& Finance, v. 43, n. 3, p. 283-309, nov. 2003.

GASPAR, J.; MASSA, M.; MATOS, P. Shareholder investment horizons and the market for corporate control. Journal of Financial Economics, v. 76, p. 135-165, 2005.

GOLEC, J. H. The effects of mutual fund managers'characteristics on their portfolio performance, risk and fees. Financial Services Review, v. 5, n. 2, p. 133-148, 1996. 
GRINBLATT, M.; TITMAN, S. Mutual fund performance: an analysis of quarterly portfolio holdings. Journal of Business, v. 62, p. 394-415, 1989.

;. Performance measurement without benchmarks: an examination of mutual fund returns. Journal of Business, v. 66, p. 47-68, 1993.

GRUBER, M. J. Another puzzle: the growth in actively managed mutual funds. Journal of Finance, v. 51, p. 783-810, 1996.

KUTNER, M. H. et al. Applied linear models. 5. ed. New York: McGraw-Hill Irwin, 2004.

LEUSIN, L. M. C.; BRITO, R. D. Market timing e avaliação de desempenho dos fundos brasileiros. RAE - Revista de Administração de Empresas, São Paulo, v. 48, n. 2, p. 22-36 abr./jun. 2008.

MARKOWITZ, H. Portfolio selection. The Journal of Finance, v. 7, n. 1, 1952.

MATOS, P.; ROCHA, A. Ações e fundos de investimento em ações: fatores de risco comuns? BBR - Brazilian Business Review, v. 6, n. 1, p. 22-43, jan./abr. 2009.

SANVICENTE, A. Z. Captação de recursos por fundos de investimento e mercado de ações. RAE - Revista de Administração de Empresas, v. 42, n. 3, p. 92-100, jul./set. 2002.

TAMHANE, A. C.; DUNLOP, D. D. Statistics and data analysis: from elementary to intermediate. Upper Saddle River: Prentice-Hall.2000.

WERMERS, R. Mutual fund performance: an empirical decomposition into stock-picking talent, style, transaction costs, and expenses. Journal of Finance, v. 85, p. 1655-1695, 2000.

WHITE, H. A Heteroskedasticity-consistent covariance matrix estimator and a direct test for heteroskedasticity. Econometrica, v. 48, n. 4, p. 817-838, 1980. 